一原 著一

\title{
有核赤血球の NADPH 依存性メトへモグロビン還元酵素*
}

ウシガェル赤血球酵素の精製と性質

\author{
伊藤 敏治 \\ 日本医科大学第 1 生化学教室 (主任：岡崎太郎教授)
}

\begin{abstract}
NADPH-dependent methemoglobin reductase in nucleated erythrocytes:
Purification and characterization of the bullfrog erythrocyte enzyme
\end{abstract}

Toshiharu Ito

The First Department of Biochemistry, Nippon Medical School

The present paper describes the purification and characterization of NADPH-dependent methemoglobin reductase from the erythrocytes of bullfrog, Rana catesbeiana. The results obtained are as follows:

1) Two active protein components having different isoelectric points (pI) of 5.0 and 7.5 were separated and purified to homogeneity.

2) Both components had the same molecular weight of 22,000 upon SDS-polyacrylamide gel electrophoresis. pI 5.0 component was faint yellow showing a broad absorption in the range of 400 $\sim 450 \mathrm{~nm}$, while pI 7.5 component was colorless showing no absorption in that range.

3) When pI 5.0 component was subjected to the second isoelectric focusing, the protein part of that component was observed to regenerate at $\mathrm{pI} 7.5$, leaving the yellow color at acid $\mathrm{pH}$. This fact strongly implies that the protein moiety of $\mathrm{pI} 5.0$ component is identical to that of $\mathrm{pI} 7.5$ component.

4) Both components catalysed the NADPH-dependent MB (or DCPIP, FMN, FAD) reduction. Kinetic studies revealed that both components were the same in their catalytic properties.

5) These structural and functional properties of the bullfrog enzyme very much resembled those of NADPH-flavin reductase in the human erythrocytes, indicating that the enzyme equivalent to that found in mammalian erythrocytes also exists in amphibian erythrocytes.

Key words: NADPH-methemoglobin reductase, nucleated erythrocyte, enzyme purification, Rana catesbeiana

\section{緒 言}

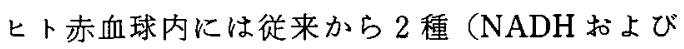
NADPH 依存性)のメトーモグロビン還元醭素の存在 が知られている。このうち前者は Hultquist ${ }^{11}$ 特よび Sugita ${ }^{2} K よ っ て N A D H-c y t o c h r o m e b_{5}$

Present address: The First Department of Biochemistry, Nippon Medical School, 1-1-5, Sendagi, Bunkyo-ku, Tokyo, 113 Japan

・本論文は学位論文である。 reductaseであることが明らかにされた，現在ではこ の酵素系がメトへモグロビン僄元の主経路であると考 えられており，またこの酵素が肝ミクロソームに存在 寸る同名酵素ときわめて類似していること年先球 の成熟に伴って膜成分より可溶化されること帛などが 報告されている。一方 NADPH 依存性醅素に関して は, Yubisui ら99よって，それがフラビン還元活性を るつことから NADPH-フラビン還元酵素と命名さ れ，前者の欠損時（遺伝性メトへモグロビン血症）に 役立つものと考觉られている(10 12). また，この酵素活 
性が等電点泳動によって, pI 6 と $\mathrm{pI} 8$ の 2 成分に分離 されることが報告13)されている。しかしこの䣼素の反 心機構や生理的役割についてはいまだ不明の点が多い。

哺乳動物以外に, 鳥類, 爬虫類, 両棲類, 魚類の有 核赤血球にも同様に 2 種のメトへモグロビン還元酵素 活性の存在することが報告 ${ }^{14 \sim 17) さ れ て い る 。 し か し ， ~}$ これらの有核赤血球内の酵素が哺乳動物のものと同じ 分子種であるか否かは，現在まで全く明らかにされて いない，著者は先に，ニワトリ扣よびウシガェル赤血 球内の両酵素活性について検討し，これらの赤血球内 ではNADH 依存性酵素がすべて膜結合型でありこ れに対してNADPH 依存性酵素は可溶性画分に存在 すること，ならびにウシガェル幼生の赤血球中には後

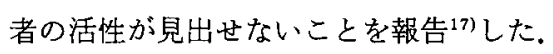

これらの知見に基づき，著者は有核赤血球に括ける メトへモグロビン還元機構を，哺乳動物赤血球との対 比のもとに明らかにしたいと考え，今回成熟ウシガエ ル赤血球より NADPH 依存性酵素を精製して, その分 子特性を検討した。その結果, 本酵素がヒト赤血球内 の NADPH メトへモグロビン還元酵素(フラビン還元 酵素）と同一の分子種と思わ机ること，しかしながら 本酵素の生理的役割が本質的にメトへモグロビンの還 元にあるとは考沈くことが明らかになった。

\section{実験材料および方法}

（1）実験材料

成熟ウシガエル $(200 〜 300 \mathrm{~g})$ は松本実験動物社より 購入した。

試薬類は, cytochrome c (ウマ心筋), flavin adenine dinucleotide (FAD), catalase および2, 3-bisphosphoglycerate (2, 3-DPG) を Boehringer Mannheim 社, 還元型 nicotinamide adenine dinucleotide (NADH)，および還元型 nicotinamide adenine dinucleotide phosphate (NADPH) Oriental Yeast Japan 社, flavin mononucleotide (FMN), o-phenanthroline 䄮よびp-chloromercuribenzoate (PCMB) を和光純薬社, superoxide dismutase (ウシ赤血球)を Sigma 社, methyleneblue (MB) を東京化成工業社, 2, 4-dichlorophenolindophenol (DCPIP) を関東化学 社, Sephadex G.75 を Pharmacia 社, DEAE- 52 cellulose Whatmann 社, Cellulofine GCL-300-m t生化 学工業株式会社, $40 \%$ Ampholine ( $\mathrm{pH} 3.5 \sim 10)$ を LKB 社より各々購入し使用した。そ他の試薬はすべ て市販の特級品を使用した。

\section{（2）実験力法}

\section{1）溶血液の調製}

成熟ウシガェルを脊髄穿刺した後開胸し，大動脈穿 刺によっていパリン加採血した，採取した血液に 5 倍 量の Krebs-Ringer 液を加光，2,500 rpm，5 分遠心し て上清およびバッフィーコートを吸引除去した。この 操作を 3 回繰り返してその都度注意深くバッフィー コートを除き, 赤血球を洗浄した後, 得られた赤血球 を2 倍量の $10 \mathrm{mM}$ Tris- $\mathrm{HCl}$ 緩衝液, $\mathrm{pH} 7.5$ (20 mM, $\mathrm{MgCl}_{2}, 1 \mathrm{mM}$ EDTA, 5.0 mM DTT, 0.1 mM PMSF を含む）に再浮遊し，アセトンドライフイスバス中で 凍結融解を繰り返して完全に溶血させた，次しでこれ を $105,000 \times \mathrm{g}, 60$ 分, $4{ }^{\circ} \mathrm{C}$ で遠心し，得られた上清を 溶血液（可溶性画分）として使用した。

2）酵素活性の測定

i .メトへモグロピン還元活性

メトへモグロビン還元活性の測定は, Agar and Harleyの方法 ${ }^{14)}$ 部分的に修正し以下のように行っ た。をた反応の基質としては，Hegesch らの方法 ${ }^{18}$ に 従って，ヒト赤血球より還元酵素を含まないメトへモ グロビン溶液を調製し使用した。

$100 \mu \mathrm{mol}$ 燐酸カリウム緩衝液, $\mathrm{pH} \quad 7.0,1 \mu \mathrm{mol}$ EDTA, $200 \mathrm{nmol}$ (へム当量) ヒトメトーモグロビン, 適当量の酵素試料，および $25 \mu \mathrm{mol} \mathrm{MB}$ （または 50 nmol DCPIP, $200 \mathrm{nmol} \mathrm{FMN,} 200 \mathrm{nmol} F A D)$ を含 む反応液の全量を $2.0 \mathrm{~m} l$ とし，これに $300 \mathrm{nmol} の$ $\mathrm{NADPH}$ (または NADH) $20 \mu l$ を添加して反応を開 始した。 反応開始後 3 分間の $576 \mathrm{~nm}$ に打ける吸光度 変化を記録し，同波長に扣ける酸素へモグロビンとメ トへモグロビンのミリモル吸光係数の差を 11.9 とし

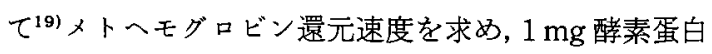
質あたりの活性（ $\mathrm{nmol} / \mathrm{min} / \mathrm{mg}$ protein）として表示 した.

\section{ii . cytochrome $\mathrm{c}$ 還元活性}

上記と同様の条件でヒトメトへモグロビンの替わり に200 nmol cytochrome c を用いて還元活性の測定を 行った. 反応開始後 3 分間にわたって, $550 \mathrm{~nm} に$ 括け る吸光度変化を記録し酸化型括よび還元型 cytochrome cのミリモル吸光俰数の差を 21.1 として ${ }^{20)}$ cytochrome $\mathrm{c}$ 還元速度を求め, $1 \mathrm{mg}$ 醉素蛋白質あた りの活性（nmol/min/mg protein）として表した。

iii. methylene blue (MB), 2, 4-dichlorophenolindophenol (DCPIP) および flavin 還元活性 $100 \mu \mathrm{mol}$ カリウム燐酸楥衝液, $\mathrm{pH} 7.0,1 \mu \mathrm{mol}$ 
EDTA，適当量の酵素試料および $25 \mu \mathrm{mol} \mathrm{MB（また}$ は $50 \mathrm{nmol} \mathrm{DCPIP,} 200 \mathrm{nmol} \mathrm{FMN}, 200 \mathrm{nmol} \mathrm{FAD}$ ) を含を反応液の全量を $2.0 \mathrm{~m} l$ とし，これに $300 \mathrm{nmol}$ NADPH（またはNADH）20 $\mu l$ を添加して反応を開 始した。 反応開始後 3 分間にわたって, $340 \mathrm{~nm}$ に和け る吸光度变化を記録し還元型 NAD (P)のミリモル吸 光係数を 6.22 として ${ }^{19} \mathrm{NAD}(\mathrm{P}) \mathrm{H}$ の酸化速度を算出 し， $1 \mathrm{mg}$ 酵素蛋白質あたりの活性 $(\mathrm{nmol} / \mathrm{min} / \mathrm{mg}$ protein）をもって還元活性とした。

3) SDS ポリアクリルフミド電気泳動(SDS-PAGE) 精製酵素のSDS-PAGE は Laemmli の方法 ${ }^{21)}$ 従った. 厚さ $1 \mathrm{~mm} の$ slab gel 用い, stacking gel には $3.5 \%$, separation gel には $18 \%$ クリルアミド を使用した。通常 $2 \% \mathrm{SDS}, 5 \% \mathrm{MSH}$ 中で $100^{\circ} \mathrm{C} 5$ 分間 の処理をした試料 $30 \mu \mathrm{g}$ をゲル上端にのせ $20 \mathrm{~mA}, 6$ 時間の条件で泳動を行った。染色には Coomassie brilliant blue-R, 脱色には 7.5\% (v/v) 酶酸, 25\% (v/v) メタノール混合液を使用した。

4）蛋白質濃度の測定

試料の蛋白質濃度はLowry らの方法 ${ }^{22}$ に従いウシ 血清アルブミンを基準として定量した，等電点分離後 の酵素試料については，アンホラインを除くために約 100 倍量の $5 \mathrm{mM}$ 憐酸カリウム緩衝液, $\mathrm{pH} 7.0,0.5$ $\mathrm{mM} \mathrm{DTT}$ 溶液で $4{ }^{\circ} \mathrm{C} 2$ 時間透析後, Lowry 变法を用 いて以下のように蛋白質濃度を測定した，蛋白質を含 む試料 $0.1 \mathrm{~m} l$ に蒸留水 $3.0 \mathrm{~m} l$ を加觉, $2 \%$ デオキシ コール酸ナトリウム溶液 $25 \mu l$ を加えてよく混和後 15 分間室温に放置した。次に $24 \%$ トリク口口酢酸溶液 $1 \mathrm{~m} l$ を加えてよく混和した後, 沈殿を $3,300 \times \mathrm{g}, 30$ 分 間遠心して集めた。得られた沈殿に $0.2 \mathrm{~m} l$ の蒸留水 を加えた溶液を試料として Lowry 法にて蛋白質濃度 を測定した.

なお，分光学的測定はすべて日立 340 型または 200-1 型自記分光光度計によった。

5） NADPH 依存性メトへモグロビン還元酥素の精 製

前述の方法で調製した溶血液の $105,000 \times \mathrm{g}$ 遠心上 清より以下の操作で酵素を精製した，操作はすべて 0 〜 $4{ }^{\circ} \mathrm{C}$ で行った.

i . Sephadex G-75によるゲルろ過

溶血液 $100 \mathrm{~m} l$ （蛋白量 8 9 g) を，あらかじめ 50 $\mathrm{mM}$ Tris- $\mathrm{HCl}$ 緩衝液, $\mathrm{pH} 8.0,0.2 \mathrm{M} \mathrm{NaCl}, 1 \mathrm{mM}$ EDTA, $0.5 \mathrm{mM}$ DTTによって平衡化した Sephadex G-75 カラム $(5 \mathrm{~cm} \times 100 \mathrm{~cm})$ に負荷し, 同じ緩衝液で
$60 \mathrm{~m} l / \mathrm{h}$ の速度で溶出した，上記カラムの容量が限ら れているため, 通常同様の操作を $7 \sim 8$ 回繰り返して, 約 $800 \mathrm{~m} l$ の溶血液を処理した.

ii. DEAE 52-cellulose カラムクロマトグラフィー Sephadex G.75カラムより溶出した活性分画を集 め, Immersible cx-10 (millipore) にて濃縮し, $2 \mathrm{mM}$ Tris- $\mathrm{HCl}$ 緩衝液, $\mathrm{pH} 8.2(1 \mathrm{mM}$ EDTA， $0.5 \mathrm{mM}$ DTTを含む)に対して一夜十分に透析を行った。これ を同緩衝液であらかじめ平衡化したDEAE 52-cellulose カラム $(5 \mathrm{~cm} \times 35 \mathrm{~cm})$ に負荷し, 約 $6 l$ の同緩 衝液で洗浄した。次いで, 上記緩衝液とこの緩衝液に $0.3 \mathrm{M} \mathrm{NaCl}$ を加えた液各々 $2,400 \mathrm{~m} l$ に上る直線勾 配をかけて溶出を行った. 溶出速度は $60 \mathrm{~m} l / \mathrm{h}$ で 11.5 $\mathrm{m} l$ ずつ分画採取した。

iii. Cellulofine GCL-300-mによるゲルろ過

DEAE 52-cellulose カラムクロマトグラフィーから 溶出した活性分画を集め, $50 \mathrm{mM}$ Tris- $\mathrm{HCl}, \mathrm{pH} 7.8$, $0.25 \mathrm{M} \mathrm{NaCl}, 1 \mathrm{mM}$ EDTA, $0.5 \mathrm{mM}$ DTT を含屯緩 衝液であらかじめ平衡化した Cellulofine GCL-300-m カラム $(3.4 \times 92 \mathrm{~cm})$ に負荷し, 同緩衝液で $60 \mathrm{ml} / \mathrm{h}$ の速度で溶出した. $6 \mathrm{~m} l$ ずつ分画採取し, 活性分画を 集めImmersible cx-10にて約 3 倍に濃縮した後 5 $\mathrm{mM}$ Tris- $\mathrm{HCl}, \mathrm{pH} 7.8,1 \mathrm{mM}$ EDTA, 0.5 mM DTT を含む緩衝液に対して一夜透析を行った。

iv. 等電点泳動（第 1 回）

透析後の試料 $15 \mathrm{~m} l$ を集め, Vesterberg の方法 ${ }^{23}$ に 従いLKB 社製 $110 \mathrm{~m} l$ 垂直カラムならびに carrier Ampholyte (pH 3.5 9.5) を用いて等電点分画を 行った. 試料はカラム中央に分割して加え, 通電は 500 V定電圧で40時間とした。この条件下で活性はpI 5.0 および pI 7.5 の 2 成分に分画された。

$\mathrm{v}$. 等電点泳動（第 2 回）

上記の等電点泳動で得られた $\mathrm{pI} 5.0$ の活性分画を Immersible cx-10 にて濃縮し, その $15 \mathrm{ml}$ を再び同様 のカラムを用いて等電点泳動した。 ただし， carrier Ampholyteは pH 4〜6のものと $\mathrm{pH} 3.5 \sim 10$ のの を 4 対 1 の割合で混合したものを用い，通電は $500 \mathrm{~V}$ 定電玨，70時間とした。

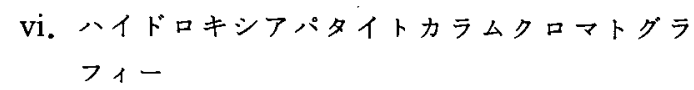

一方, 第 1 回の等電点泳動によって得た $\mathrm{pI} 7.5$ の分 画を Immersible cx-10 とて濃縮し，その $19 \mathrm{~m} l$ を 100 倍量の $5 \mathrm{mM}$ 燐酸カリウム楥衝液, $\mathrm{pH} 7.0(0.5 \mathrm{mM}$ DTTを含む)に対して透折した後，LKB 社製 
ULTROCHROM GTi HPLCシステムを用いてハイ ドロキシフパタイカラムクロマトグラフィーを行っ た，使用したカラムはヒドロキシアパタイトカラム (7.5 mm $\times 100 \mathrm{~mm}$ ) (東亜然料工業株式会社), 溶出液 は $\mathrm{A}$ 液： $5 \mathrm{mM}$ 燐酸カリウム緩衝液 $\mathrm{pH} 7.0$, 抽よび
B液： $500 \mathrm{mM}$ 燐酸カリウム緩衝液 $\mathrm{pH} 7.0$ を用い た。グラジェントは $100 \% \mathrm{~A}$ 液 $\rightarrow 100 \% \mathrm{~B}$ 液 $/ 45$ 分, 流 速は $0.7 \mathrm{ml} / \mathrm{min}$, 温度は室温の条件で行った。試料は 1 回に $0.5 \mathrm{ml}$ （約 $1 \mathrm{mg}$ 蛋白質を含む）ずつ注入し, 最終的に $15 \mathrm{~m} l$ を処理した. 活性分画を集め Immersi-

Table 1 Purification of NADPH-methemoglobin reductase from bullfrog erythrocytes

\begin{tabular}{l|rcccr}
\hline \multicolumn{1}{c|}{ Step } & $\begin{array}{c}\text { Total } \\
\text { Protein } \\
\text { (mg) }\end{array}$ & $\begin{array}{c}\text { Total } \\
\text { Activity } \\
\text { (nmol/min) }\end{array}$ & $\begin{array}{c}\text { Specific } \\
\text { Activity } \\
\text { (nmol/min/mg) }\end{array}$ & $\begin{array}{r}\text { Yield } \\
\text { (\%) }\end{array}$ & $\begin{array}{c}\text { Purification } \\
\text { Factor }\end{array}$ \\
\hline 1. Hemolysate & 76,870 & 69,183 & 0.9 & 100 & 1 \\
2. Sephadex G-75 & 8,820 & 69,378 & 7.9 & 100 & 9 \\
3. DEAE 52-cellulose & 1,016 & 82,689 & 81.4 & 120 & 90 \\
4. Cellulofine GCL-300-m & 202 & 66,554 & 329 & 96 & 365 \\
5. 1st IEF & & & & & \\
$\quad$ pI 5.0 & 25.6 & 2,258 & 88 & 3.2 & 98 \\
$\quad$ pI 7.5 & 44.1 & 6,628 & 150 & 9.5 & 167 \\
6. 2nd IEF & & & & & \\
$\quad$ pI 5.0 & 3.2 & 727 & 227 & 1.0 & 252 \\
$\quad \begin{array}{l}\text { Hydroxyapatite(HPLC) } \\
\quad \text { pI 7.5 }\end{array}$ & 5.0 & 979 & 196 & 1.4 & 218 \\
\hline
\end{tabular}

Enzyme activity was measured by following the reduction of methemoglobin at $576 \mathrm{~nm}$ in the presence of $0.15 \mathrm{mM}$ NADPH and $12.5 \mathrm{mM}$ methylene blue as described in Methods, and was expressed in terms of nmole methemoglobin reduced per minutes.

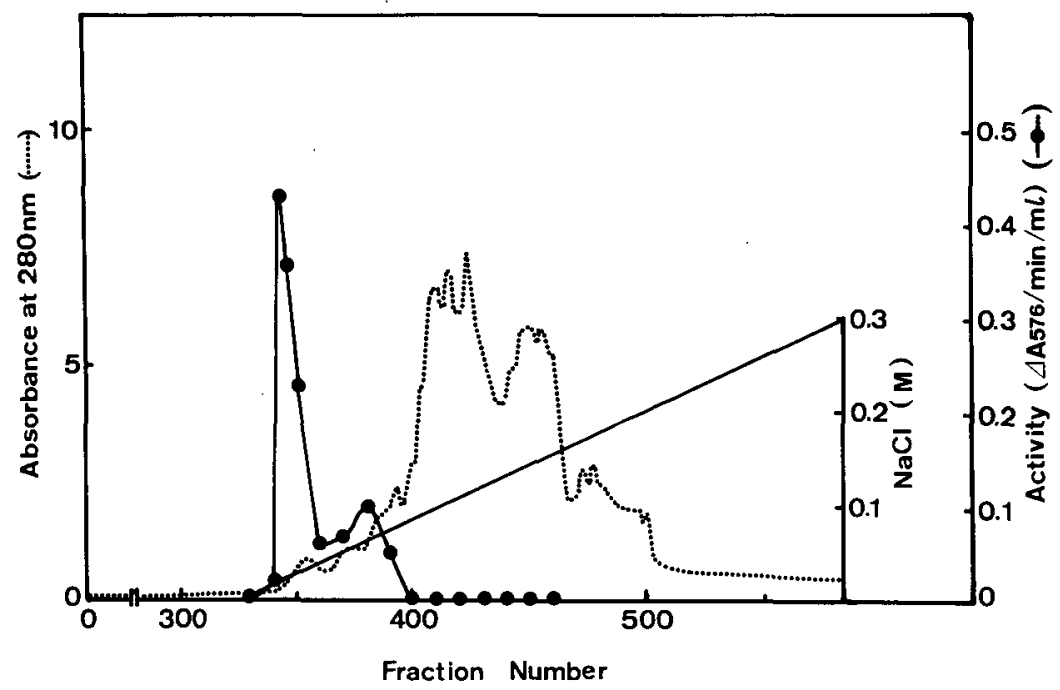

Fig. 1 Elution profile of NADPH-methemoglobin reductase from DEAE-cellulose column

Fractions eluted from Sephadex G-75 $(2,400 \mathrm{~m} l, 8,820 \mathrm{mg}$ protein) was applied to the column $(5 \mathrm{~cm} \times 35 \mathrm{~cm})$ equilibrated with $2 \mathrm{mM}$ Tris- $\mathrm{HCl}$ buffer, containing $1 \mathrm{mM}$ EDTA and $0.5 \mathrm{mM}$ DTT, $\mathrm{pH} 8.2$. After the washing with $6,000 \mathrm{~m} l$ of the same buffer, the column was developed with a linear gradient formed between $2,400 \mathrm{ml}$ each of $2 \mathrm{mM}$ Tris. $\mathrm{HCl}$ buffer containing $1 \mathrm{mM}$ EDTA and $0.5 \mathrm{mM}$ DTT, $\mathrm{pH} 8.2$, and $0.1 \mathrm{M} \mathrm{NaCl}$ in the same buffer. The flow rate was $60 \mathrm{~m} l / \mathrm{h}$ and fractions of $11.5 \mathrm{~m} l$ were collected. The enzyme activity was assayed as described in Methods. 
ble cx-10にて約 4 倍に濃縮し, 次に使用するまで $4{ }^{\circ} \mathrm{C}$ で保存した。

\section{結 果}

\section{1. 酵素の精製}

従来ヒト赤血球に存在する NADPH 依存性メト一 モグロビン還元酵素は in vitroで NADPHを電子供 与体として methylene blue の存在下に強いメトへモ グロビン還元活性を示し，また DCPIPを直接還元す る強い diaphorase 活性を示すことが知られている。 われわれはすでにウシガエル赤血球でもこれと同様の

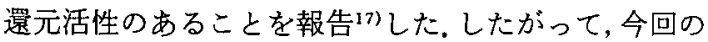
ウシガエル赤血球からの本酵素の精製に際しては，全 過程を通じて methylene blue 存在下でのメトへモグ ロビン還元活性を測定して精製の指標とした。

精製の全過程を Table 1 に示した。 また，Fig. 1 は DEAE-52 cellulose カラムクロマトグラフィー（Step 3）の溶出曲線である. Fig. 1 のごとく酵素活性は $\mathrm{NaCl}$ 濃度 $0.02 \mathrm{M}$ 付近に主ピークとして溶出された。 Step 1 4 の過程で夾雑蛋白質（主としてへモグロビ ン）の大部分が除去され，これらの操作はきわめて効

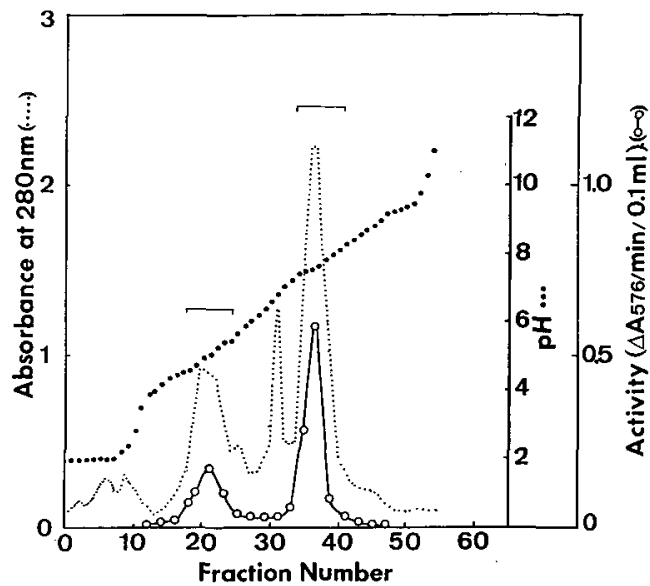

Fig. 2 Isoelectric focusing of NADPH-methemoglobin reductase

The enzyme sample eluted from a Cellulofine GCL-300-m column ( $33 \mathrm{ml}, 202 \mathrm{mg}$ ) was subjected to isoelectric focusing performed by using a LKB 8101 column and carrier am. pholine, $\mathrm{pH} 3.5 \sim 9.5$. Focusing was carried out at $500 \mathrm{~V}$ for $40 \mathrm{hs} .1 .5 \mathrm{ml}$ fractions were collected and the activity (solid line) and the absorbance at $280 \mathrm{~nm}$ (dotted line) were measured. pI 5.0 and pI 7.5 fractions each indicated by bar were pooled separately.

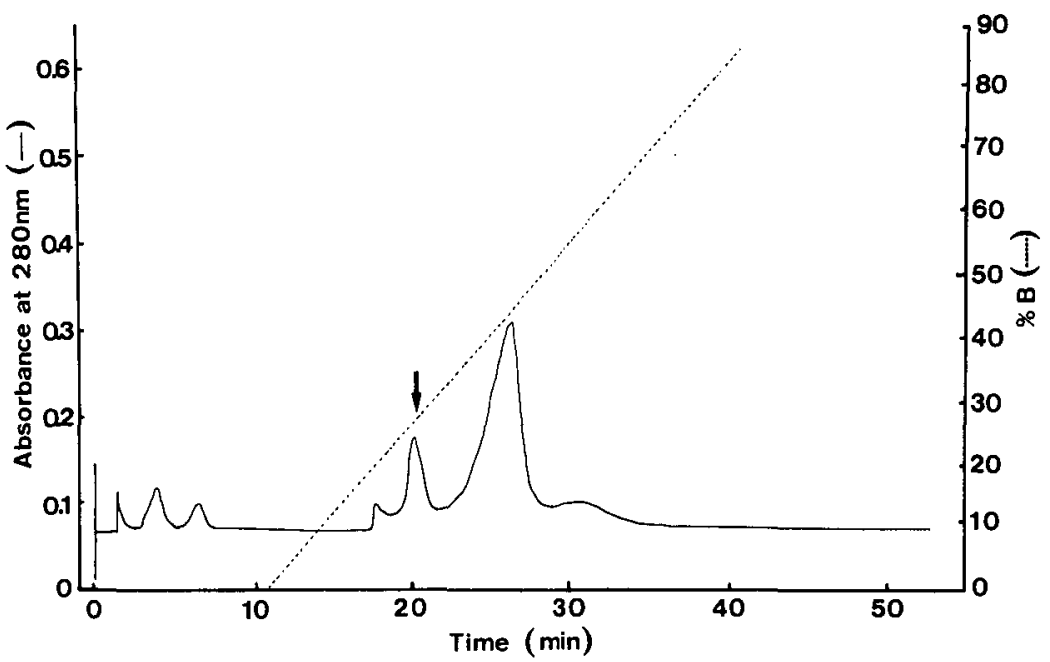

Fig. 3 Elution profile of hydroxyapatite column chromatography (HPLC)

A hydroxyapatite column chromatography was performed for the pI 7.5

fraction separated by the first isoelectric focusing, using a LKB ULTRO-

CHROM GTi HPLC system.

Eluent : solution $\mathrm{A} ; 0.005 \mathrm{M} \mathrm{K}_{2} \mathrm{HPO}_{4} / \mathrm{KH}_{2} \mathrm{PO}_{4}, \mathrm{pH} 7.0$

solution $\mathrm{B} ; 0.5 \mathrm{M} \mathrm{K}_{2} \mathrm{HPO}_{4} / \mathrm{KH}_{2} \mathrm{PO}_{4}, \mathrm{pH} 7.0$

Gradient : $100 \% \mathrm{~A} \cdot 100 \% \mathrm{~B} / 45 \mathrm{~min}$

Flow rate $: 0.7 \mathrm{~m} l / \mathrm{min}$

Detection : 0.64 AUSF, $280 \mathrm{~nm}$

Injection volume : $500 \mu l$

Arrow indicates the enzyme fraction. 
果的であった。

Fig. 2 は最初の等電点泳動 (Step 5) の結果である. 図のごとく, 酵素活性はこの過程で pI 5.0 と pI 7.5 の 2 成分に分離した。指吸ら ${ }^{13)}$ は, ヒト赤血球の NADPHメトへモグロビン還元酵素にも等電点の異 なる 2 成分 $(\mathrm{pI} 6,8)$ が存在することを報告しており, 今回の事実はこれとよく一致する。 pI 5.0 の成分は再 度の等電点泳動で, また $\mathrm{pI} 7.5$ の成分はハイドロキシ アパタイトカラムを用いた HPLC (Fig. 3) で, 各々 最終的に 258 倍（pI 5.0），218 倍（pI 7.5）に精製し た. 注目すべきことに，第 2 回の等電点泳動 (Step 6) で pI 5.0 の成分は再び pI 5.0 と pI 7.5 の 2 成分に分 離した。著者は現在これを何らかの理由により, pI $5.0,7.5$ の両成分が互いに移行する結果と考えている (後述).

酵素の比活性に関しては, Step 4 から Step 5 への段 階でかなりの低下が認められた。 これが蛋白質の変性 によるものか, あるいは何らかの補助因子が除去され たためかは現在のところ不明である.

\section{2. 精製酵素の電気泳動および吸収スペクトル}

Fig. 4 は精製酵素の SDS-ポリアクリルアミドゲル 電気泳動像である。両成分とも単一なバンドとして泳 動され, これから分子量はともに 22,000 と求められ た. この值はヒト赤血球内の酵素と一致する ${ }^{19)}$.

両成分の吸収スペクトルを Fig. 5 に示した. 図のご

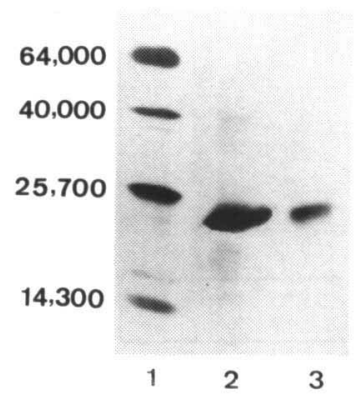

Fig. 4 SDS-polyacrylamid gel electrophoresis of the purified enzyme (pI 5.0 and $\mathrm{pI} 7.5$ )

The purified samples were applied to a $18 \%$ polyacrylamide gel containing $0.1 \%$ SDS with $0.05 \%$ bromophenol blue as a tracking dye. The markers used were BSA (mol. wt. 64,000 ), creatine kinase (mol. wt. 40,000), chymotrypsin (mol. wt. 25,700), and lysosome (mol. wt. 14,300). Gels were stained with Coomassie blue: lane 1 ; markers, lane 2 ; pI 5.0, lane 3 ; pI 7.5.
とく pI 5.0 の成分は, 可視領域で $420 \mathrm{~nm}$ 付近になだ らかな低い吸収を示し, 紫外領域では $285 \mathrm{~nm}$ 付近に 肩吸収を, $270 \mathrm{~nm}$ に吸収極大を示した.一方 pI 7.5 の 成分は可視領域に全く吸収を示さず, $270 \mathrm{~nm}$ に単一な ピークを示した. pI 5.0 の成分は肉眼的に淡黄色を呈 し, pI 7.5 成分は無色であった。 前者の色調は $420 \mathrm{~nm}$ 付近の吸収に由来すると思われるが, 試料に $\mathrm{Na}_{2} \mathrm{~S}_{2} \mathrm{O}_{4}$ を添加してもスペクトル上に変化は認められなかっ た.

以上のごとく, 精製した pI 5.0 および 7.5 の両酵素 成分は可視部吸収スペクトルに若干の差異を示した。 しかしながら, 以下に述べる反応上の諸特性に関して は, 両成分の間にほとんど有意の差が認められなかっ た.したがって以下の記述には pI 5.0 の成分について 得られた結果のみを記載した。

\section{3. 酵素活性の $\mathbf{p H}$ 依存性}

Fig. 6 に NADPH を電子供与体としたときの本酵 素（pI 5.0 の成分）による-NADPH-methylene blueメトヘモグロビン還元活性 (NADPH-MB-metHb 反 応）抌び DCPIP 還元活性（NADPH-diaphorase 反 応)の $\mathrm{pH}$ 依存性を示した. NADPH-MB-metHb 反応 の測定には, 低 $\mathrm{pH}$ 領域でクェン酸緩衝液, 高 $\mathrm{pH}$ 領域 で燐酸カリウム緩衝液を用いた. NADPH-diaphorase 反応は, DCPIP が pH 6 以下の酸性領域で不安定なた め, 燐酸カリウム緩衝液の領域でのみ測定を行った。

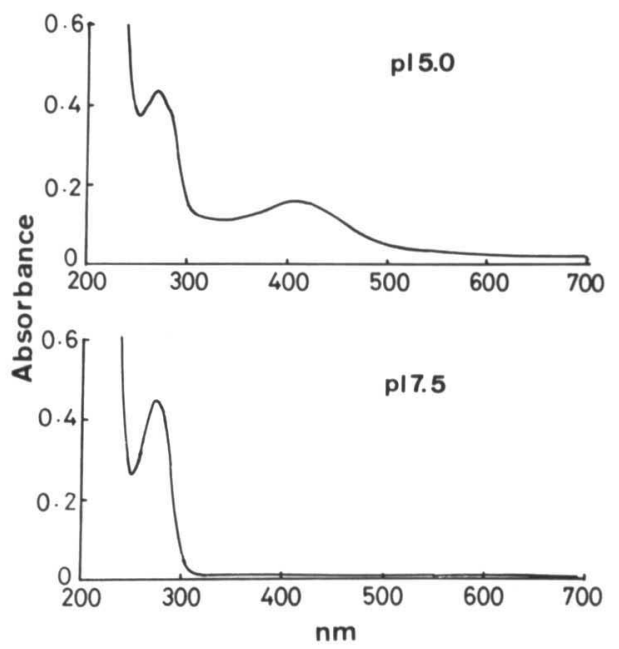

Fig. 5 Absorption spectra of the purified enzyme (pI 5.0 and pI 7.5)

The spectra were measured in $0.05 \mathrm{M}$ potassium phosphate buffer, pH 7.0. 


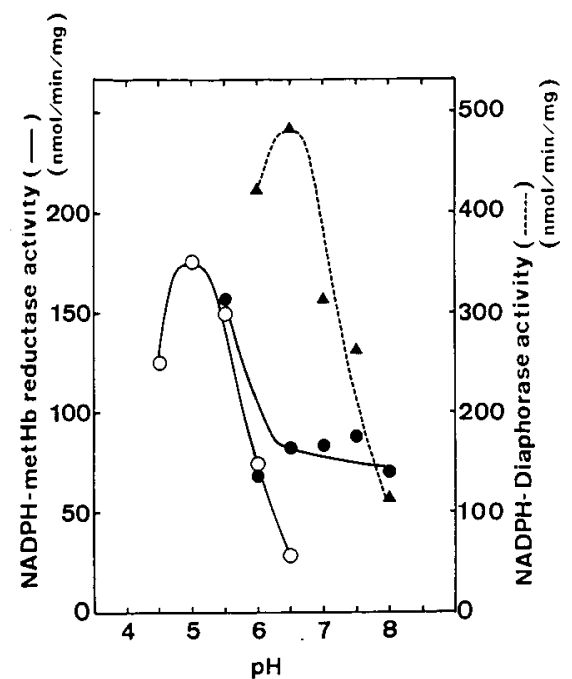

Fig. 6 Effects of $\mathrm{pH}$ on the NADPH-MBmethemoglobin reductase and NADPHdiaphorase activity (pI 5.0)

The assay conditions were as described in Methods: solid lines, NADPH-MB-methemoglobin reductase activity (open circle ; $50 \mathrm{mM}$ citrate-phosphate buffer, $\mathrm{pH}$ 4.5 6.5, closed circle; $50 \mathrm{mM}$ potassium phosphate buffer, pH 5.5 8.0), dotted line, NADPH-diaphorase activity.

結果は図のごとくNADPH-MB-metHb 反応は pH 5.0 K, NADPH-diaphorase 反応は $\mathrm{pH} 6.5$ に至適 $\mathrm{pH}$ を示した. Yubisui ら ${ }^{19}$ は七ト赤血球の NADPHflavin 還元酵素について，NADPH-FMN 還元反応打 よびNADPH-diaphorase 反応の $\mathrm{pH}$ 依存性を報告し ているが，今回の結果はYubisui らの值ときわめて良 く一致し, 興味深い.

\section{4. 電子供与体および受容体に対する反応特異性}

Table 2 にNADH および NADPH を電子供与体 として諸種の電子受容体に対する本酵素（pI 5.0 の成 分）の還元活性を $\mathrm{pH} 7.0$ に括いて測定した結果を示 した，表に明らかなごとく本酵素は NADH-MB 反応 でわずかな活性を示す汪かは, 明らかに NADPH 依存 性を示した。 NADPHを電子供与体とした場合, MB および DCPIP の両人工色素に対する還元活性が最も 強く,これに対してFMNに対する還元活性はMBの 場合の $1 / 6$ であり，FADに対する活性は $1 / 40$ にすぎ なかった。 またフフェリサイアナイドに対しては活性 を示さなかった。

一方，メトへモグロビン拈よび cytochrome c に対
Table 2 Specificity of NADPH-methemoglobin reductase of bullfrog erthrocytes for various electron acceptors

\begin{tabular}{l|lcc}
\hline $\begin{array}{c}\text { Electron } \\
\text { Acceptors }\end{array}$ & (mM) & $\begin{array}{c}\text { NADH } \\
\text { (nmol/min/mg) }\end{array}$ & $\begin{array}{c}\text { NADPH } \\
\text { MB }\end{array}$ \\
DCPIP & $(12.5)$ & 6.1 & 151.6 \\
FMN & $(0.025)$ & 0 & 252.8 \\
FAD & $(0.1)$ & 0 & 25.2 \\
Ferricyanide & $(0.1)$ & 0 & 4.0 \\
metHb & $(0.2)$ & 0 & 0 \\
cyt. c & $(0.1)$ & 0 & 0 \\
\hline
\end{tabular}

The activity was measured by following the oxidation of $\mathrm{NAD}(\mathrm{P}) \mathrm{H}$ at $340 \mathrm{~nm}$ in the assay mixture as described in Methods. Zero means that there was no significant change in the absorbance as compared with control in which the enzyme had been omitted.

する還元活性も全く認められず，これらの蛋白質が直 接還元の基質にはなりえないことが示唆された。

Fig. 7 に pH 7.0 に括いて，本䤃素 (pI 5.0 の成分) の NADPH および FMN に対する Km 值を測定した 結果を示した，図から $\mathrm{NADPH} に$ 対する $\mathrm{Km}$ 值は $1.2 \times 10^{-6}, \mathrm{FMN}$ に対する $\mathrm{Km}$ 值は $3.6 \times 10^{-5}$ と求め られた。これらの值はともにYubisui らのがヒト赤血 球の酵素について得た值とほぼ一致する.

\section{5.メトへモグロビンおよひ cytochrome c 還元活} 性

すでに述べたように，本酵素はメトへモグロビンお よび cytochrome c を直接に還元しないが, 特定の色 素（中間電子伝澾体）の存在下では両者に対して還元 活性を示す。本酵素の生理的機能を検討する目的で MB，FMN，および FADを中間電子伝達体とした場 合の両蛋白質に対する還元活性を測定した。結果を Table 3 に示した. 反応はいずれも強いNADPH 依存 性を示し，NADH を電子供与体とした場合には MB の存在下でのみ弱い還元活性が認められた。表から, メトへモグロビン拉よび cytochrome cいずれの場合 でも，MBを介する反応に比べて生理的物質である FMN またはFADを介した反応速度が著しく低いこ とならびにすべての場合にメトへモグロビンょりも cytochrome c に対する還元速度のほうが高いことが 指摘される。この事実は本酵素の生理的役割がフラビ ンを介したメトへモグロビンの還元にあることに疑義 をいだかせるむのである。 

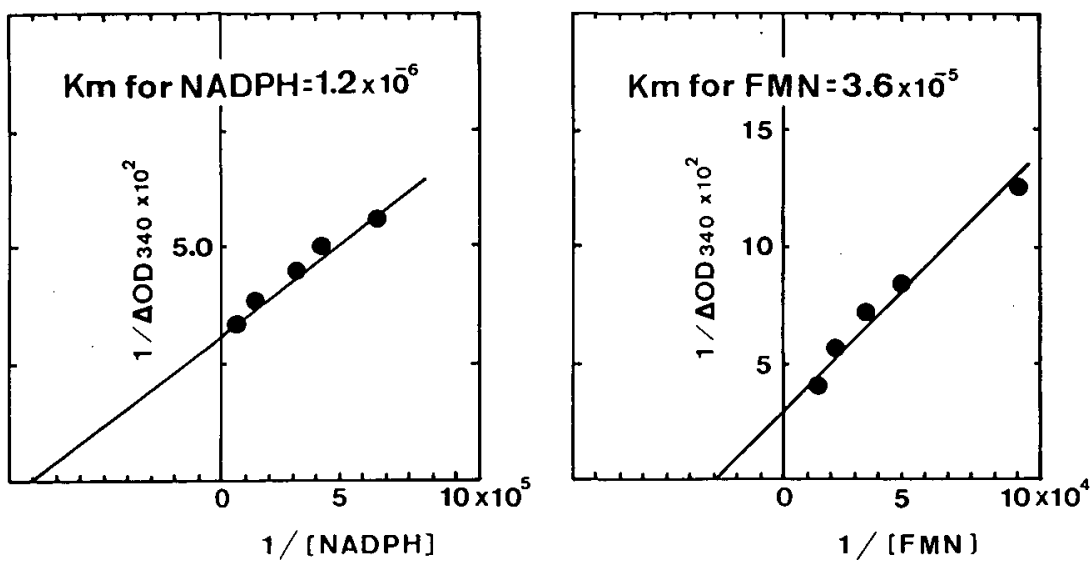

Fig. $7 \mathrm{Km}$ for NADPH and FMN of NADPH-methemoglobin reductase (pI 5.0) of bullfrog erythrocytes

The enzyme activity was measured in $50 \mathrm{mM}$ potassium phosphate buffer, $\mathrm{pH}$ 7.0 , containing $1 \mathrm{mM} \mathrm{EDTA}$, at $25^{\circ} \mathrm{C}$, by following the oxidation of NADPH at $340 \mathrm{~nm}$. The $\mathrm{Km}$ for NADPH was determined in the presence of $100 \mu \mathrm{M}$ FMN and the Km for FMN was in the presence of $150 \mu \mathrm{M} \mathrm{NADPH}$, respectively. All reactions were started by the addition of NADPH.

Table 3 Reduction of methemoglobin and cytochrome c by NADPH-methemoglobin reductase of bullfrog erythrocytes in the presence of electron mediators

\begin{tabular}{l|cr}
\multicolumn{1}{c|}{ Reaction } & \multicolumn{2}{c}{$\begin{array}{c}\text { NADH } \\
(\mathrm{nmol} / \mathrm{min} / \mathrm{mg})\end{array}$} \\
\hline MB-metHb & 3.5 & 200.0 \\
FMN-metHb & 0 & 20.0 \\
FAD-metHb & 0 & 6.2 \\
MB-cyt. c & 14.9 & 297.7 \\
FMN-cyt. c & 0 & 74.4 \\
FAD-cyt. c & 0 & 13.2 \\
\hline
\end{tabular}

Assay mixture contained $50 \mathrm{mM}$ potassium phosphate buffer, pH 7.0, containing $0.5 \mathrm{mM}$ EDTA, $0.15 \mathrm{mM}$ $\mathrm{NAD}(\mathrm{P}) \mathrm{H}$, electron mediators $(12.5 \mathrm{mM} \mathrm{MB}, 0.1 \mathrm{mM}$ FMN or $0.1 \mathrm{mM}$ FAD), $0.1 \mathrm{mM}$ metHb or cytochrome c (cyt.c), and an appropriate amount of enzyme. The reaction was started by the addition of $N A D(P) H$. The activity was measured by following the reduction of methemoglobin at $576 \mathrm{~nm}$ or cyt. c at $550 \mathrm{~nm}$, as described in Methods.

\section{6. 䤃素活性に影響を及ぼす諸因子}

Table 4 に，本酵素反応に対する諸種阻害凨拉よび 金属などの影響を NADPH-FMN-cytochrome c 反応 を用いて検討した結果を示した、表に明らかなごとく， 反応は pCMB および o-phenanthroline によって強く 阻害されたが，KCN，諸種の金属イオンならびに catalase およびSODは反応にはとんど影響を与えな
Table 4 Effects of various reagents on the enzyme activity

\begin{tabular}{l|lc}
\hline \multicolumn{1}{c|}{ Addition } & \multicolumn{1}{c}{$(\mathrm{mM})$} & $\begin{array}{c}\text { Relative activity } \\
(\%)\end{array}$ \\
\hline None & & 100 \\
pCMB & $(0.5)$ & 12 \\
o-phenanthroline & $(0.5)$ & 22.9 \\
$\mathrm{KCN}$ & $(1.0)$ & 93 \\
$\mathrm{Cu}^{2+}$ & $(0.1)$ & 112 \\
$\mathrm{Zn}^{2+}$ & $(0.1)$ & 112 \\
$\mathrm{Fe}^{2+}$ & $(0.1)$ & 96 \\
catalase & $(650$ units $)$ & 105 \\
SOD & $(30$ units $)$ & 79.5 \\
\hline
\end{tabular}

The reaction mixture contained $50 \mathrm{mM}$ potassium phosphate, pH 7.0, 0.5 mM EDTA, 0.15 mM NADPH, $0.1 \mathrm{mM}$ FMN, $0.1 \mathrm{mM}$ cyt.c, the effectors, and an appropriate amount of the enzyme. The reaction was started by the addition of NADPH and the activity was measured by following the reduction of cyt.c at $550 \mathrm{~nm}$.

かったまた，ここには示さなかったが，本酵素によ る NADPH-FMN 還元反応抌よびNADPH-diaphorase 反応も， pCMB および o-phenanthroline（ともに $5 \mathrm{mM}$ によって強く阻害された。これらの結果から， 本醭素反応には SH 基が必須であることが示唆され る、一方 catalase 拈よびSODに関しては, 後者に若干 の阻害効果が認められたが，この結果から本酵素反応 に本質的に活性酸素が関与するとは考えられない. 


\section{考 察}

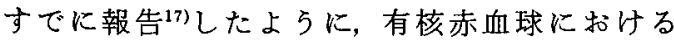
NADPH 依存性メトへモグロビン (metHb) 還元酵素 活性は，可溶性画分にのみ存在した。したがって今回 その精製にあたっては，溶血液の $105,000 \times \mathrm{g}$ 上清を 用いた。精製過程の指標には NADPH-MB-metHb 還 元活性を用いたが，NADPH-diaphorase 活性は DCPIPがカエル溶血液中で非特暴的に還元されるた め用いなかった。

結果に示したように，酵素活性は等電点の異なる 2 成分，pI 5.0 扰よび $\mathrm{pI} 7.5$ に分離した。これはヒト赤 血球の NADPH-フラビン還元酵素が $\mathrm{pI} 6$ と $\mathrm{pI} 8$ に分 離する ${ }^{13)} こ と と$ 対比され，特記すべき事柄である。精製 した両成分の分子量は同一であったが，pI 5.0 の成分 は淡黄色を示し，pI 7.5 の成分は無色であった，前者 は紫外部のほかに 400〜450 nm に明らかな吸収を示 し，何らかの色素を結合しているものと思われた，興 味あることに, pI 5.0 の成分を再度カラムまたはゲル ベッドによる等電点泳動にかけると，その蛋白質部分 が段階的に色素と分離して $\mathrm{pI} 7.5$ の成分に移行する 事実が観察された。しかもこのように新生した pI 7.5 の成分の酵素活性はpI 5.0 と同一であった。この事串 から著者らは両成分が同一蛋白質であると考点, 現在 両者の $\mathrm{N}$ 末端了ミ，酸配列を解析しているが，これま でに $\mathrm{N}$ 末端から 27 の配列が全く等しいことを碓認し ている(阿部靖子，伊藤敏治：未発表)。したがって， 両者は同一の蛋白質であり, pI 5.0 の成分は pI 7.5 の 成分に何らかの色素が結合したものと結論される。指 吸ら ${ }^{13)}$ はヒト赤血球の $\mathrm{pI} 6$ の成分が黄色の色素を結 合していることを報告している。したがって，この事 実からもとトとウシガエル両赤血球のこの醅素は同一 の性質を有することが示唆される，色素の同定はいる だ行っていないが，その吸収スペクトルからみて， ムの代謝物の可能性が強い。この物質の同定は本酵素 の生理的機能を解明する上で重要と考えられる.

前述したように, 今回精製した両 $\mathrm{pI}$ 成分の諸反応に おける特性はほとんど同一であった。したがって，反 応特性に関しては pI 5.0 の結果のみを記載したが，pI 7.5 の結果もこれと等しい,両者はともに強い NADPH 依存性を示し，これを電子供与体としてMB および DCPIPに強い還元活性を示した。すた FMN およびFADを還元したが ferricyanideは還元しな かった，metHb拈よび cytochrome c を直接還元しな
かったが，MBまたはフラビンを介して両者を還元し た.これらの反応における両 $\mathrm{pI}$ 成分の比活性はほぼ同 じであった，一方，今回測定したすべての反応特性に ついて, これをとト赤血球内の酵素と比べると, FMN 還元反応の比活性が $25.2 \mathrm{nmol} / \mathrm{min} / \mathrm{mg}$ （ヒトでは $370 \mathrm{nmol} / \mathrm{min} / \mathrm{mg})^{199}$ と低かった点を除いてヒト酵素 の特性とさわめてよく一致した。

以上の知見を総合すると，ウシガェル有核赤血球に もヒトをはじめとする哺乳類赤血球と同一の分子特性 をもった NADPH 依存性酵素が存在すること，また反 応特性の相似性からも，有核赤血球に打ける本酵素の 生理的役割む同一であることが推論される.

Yubisui ら9はヒト赤血球に㧊ける本酵素の生理的 機能をフラビン (FMN) の還元炕あると考光, フラビ ン還元酵素と名付けた。この考古によれば, metHb 還 元の機構は

$$
\left.\begin{array}{l}
\mathrm{NADPH}_{2} \\
\mathrm{NADP}^{+}
\end{array}\right)\left(\begin{array}{l}
\mathrm{FMN} \\
\mathrm{FMNH}_{2}
\end{array}\right)\left(\begin{array}{l}
\text { ferrous } \mathrm{Hb} \\
\text { metHb (ferric Hb) }
\end{array}\right.
$$

であり，本酵索はフラビンの還元のみを触媒し， metHbは $\mathrm{FMNH}_{2}$ にっって非酵素的に還元される。 また前者の反応（フラビン還元）が後者に比してきわ めて遅く，律速段階之考えられている。ウシガェル酵 素についても，その還元活性は低かったが，NADPH および FMN に対する $\mathrm{Km}$ 値はヒト酵素の値とよく 一致するので，同様の生理的機能を考えるのが妥当か もしれない，しかしながら，今回ウシがェル酵素につ いて NADPH-FMN-metHb および NADPH-FMNcytochrome c 反応を測定したところ， cytochrome c 還元反応の速度が metHb 還元反応より約 3.5 倍大き い結果を得た。この事実は本醳素が FMN の還元段階 にのみ関与し，またそれが律速段階であるといら論議 に矛盾して和り，本酵素が metHbないしはcytochrome c 分子とも相互作用を有することを示唆して いる。そうであるとすれば cytochrome c のほらがよ い基質であり, metHb が本酵素の特異的基質とはい省 ない：これらの考觉は，本酵素には未知の基質があり その還元が赤血球内に扣ける本酵素の生理的機能であ る可能性を生じさせるものである。

\section{結 論}

1）ウシガェル赤血球の溶血液 $105,000 \times \mathrm{g}$ 上清か ら，ダルろ過，イオン交換クロマトグラフィー，等電 点泳動によってNADPH 依存性メトへモグロビン還 
元醅素を精製した。

2）酵素活性は，等電点泳動によって pI 5.0 おび pI 7.5 の 2 成分に分離した。 pI 5.0 成分の吸収スペク トルは紫外領域の吸収の外に可視領域 $(400 \sim 450 \mathrm{~nm})$ になだらかな吸収を示した。 pI 7.5 成分には可視領域 の吸収が認められなかった。しかしながら両者の分子 量は SDS-PAGE上ともに22,000であり，反応特性に あ差異がなく，両成分は本質的には同一の蛋白質であ ると考光られ，pI 5.0 成分は pI 7.5 成分に何らかの色 素が結合したものと考えられた。

3）酔素活性はNADPH に強い依存性を示し，至適 $\mathrm{pH}$, 諸種電子受容体に対する反応特性，ならびに諸種 活性阻害物質に対する反応特性などいずれもヒト赤血 球の NADPH-フラビン還元酵素と類似していた。

4）以上の分子特性から本酵素がヒト赤血球の酵素 と同一分子種であると考えられるが，メトへモグロビ ン還元速度よりも cytochrome c 還元速度が大きいな ぞ，生理的機能がメトへモグロビン還元以外にある可 能性が示唆された。

稿を終わるにあたり，直接御指導いただいた第 1 生化学教室阿 部靖子博士, 目澤憲一博士(現日本医科大学付属病院小児科), な らびに教室員各位に深く感謝致します。

\section{文 献}

1) Hultquist, E.D. : Soluble cytochrome $b_{5}$ reductase from human erythrocytes. Biochim. Biophys. Acta, 275, $62 \sim 73,1972$.

2) Sugita, Y., Nomura, S. and Yoneyama, Y.: Purification of reduced pyridine nucleotide dehydrogenase from human erythrocytes and methemoglobin reduction by the enzyme. J. Biol. Chem., 246, 6072 6078, 1971.

3) Mihara, K. and Sato, R.: Partial purification of NAD. $\mathrm{PH}$-cytochrome $b_{5}$ reductase from rabbit liver microsomes with detergents and its properties. J. Biochem., 71, 725 -735, 1972.

4) Spatz, L. and Strittmatter, P.: A form of redused nicotinamide adenine dinucleotide-cytochrome $b_{5}$ reductase containing both the catalytic site and an additional hydrophobic membrane-binding segment. J. Biol. Chem., 248, 793 799, 1973.

5) Kuma, F., Prough, R.A. and Masters, B.S.S.: Studies on methemoglobin reductase. Arch. Biochem. Biophys., 172, $600 \sim 607,1976$.

6) Borgese, N., Macconi, D., Parola, L. and Pietrini, G.: Rat erythrocyte NADH-cytochrome $b_{5}$ reductase. J. Biol. Chem., 257, 13854 13861, 1982.

7) Goto-Tamura, R., Takesue, Y. and Takesue, S.: Immunological similarity between NADH-cytochrome $b_{5}$ reductase of erythrocytes and liver microsomes. Biochim.
Biophys. Acta, 423, 293 302, 1976

8) Slaughter, S.R. and Hultquist, D.E.: Membrane-bound redox proteins of the murine friend virus-induced erythroleukemia cell. J. Cell Biol., 83, 231 239, 1979.

9) Yubisui, T., Matsuki, T., Tanishima, K., Takeshita, M. and Yoneyama, Y.: NADPH-flavin reductase in human erythrocytes and the reduction of methemoglobin through flavin by the enzyme. Biochem. Biophys. Res. Comm., 76, 174 182, 1979.

10) Kaplan, J.C. and Chirouze, M.: Therapy of recessive congenital methemoglobinemia by oral riboflavine. Lancet, II(8098), 1043 1044, 1978.

11) Matsuki, T., Yubisui, T., Tomoda, A., Yoneyama, Y., Takeshita, M., Hirano, M., Kobayashi, K. and Tani, Y.: Acceleration of methemoglobin reduction by riboflavin in human erythrocytes. Br. J. Haematol., 39, 523 528, 1978.

12) Hirano, M., Matsuki, T., Tanishima, K., Takeshita, M., Shimizu, S., Nagamura, Y. and Yoneyama, Y.: Congenital methemoglobinemia due to NADH methemoglobin reductase deficiency; Successful treatment with oral riboflavin. Br. J. Haematol., 47, 353 -359, 1981.

13）指吸俊次，田村実，竹下正純：黄色色素を結合したヒ卜赤血 球の NADPH-フラビン還元酻素. 生化学, 57, 869, 1985.

14) Agar, N.S. and Harley, J.D.: Erythrocytic methemoglobin reductase of various mammalian species. Exper. ientia, 15, 1248 1249, 1972.

15) Board, P.G., Agar, N.S., Gruca, M. and Shine, R.: Methemoglobin and its reduction in nucleated eryth. rocytes from repitiles and birds. Comp. Biochem. Physiol. [B], 57, 265 267, 1977.

16) Freeman, L., Beitinger, T.L. and Huey, D.W.: Methemoglobin reductase activity in phylogenetically diverse piscine species. Comp. Biochem. Physiol. [B], 73, 27 30, 1983.

17) Ito, T., Mezawa, K. and Okazaki, T.: NADH- and $\mathrm{NADPH}$-dependent reduction of methemoglobin in the nucleated erythrocytes from hen and bullfrog. Comp. Biochem. Physiol. [B], 78, 683 686, 1984.

18) Hegesh, E., Calmanovici, N. and Avron, M.: New method for determining ferrihemoglobin reductase (NADH-methemoglobin reductase) in erythrocytes. J. Lab. Clin. Med., 72, 339 344, 1968.

19) Yubisui, T., Matsuki, T., Takeshita, M. and Yoneyama, Y.: Characterization of the purified NADPH-flavin reductase of human erythrocytes. J. Biochem., 85, 719 $\sim 728,1979$.

20) Bassey, V.: The microestimation of succinate and the extinction coefficient of cytochrome c. Biochim. Biophys. Acta, 34, 255 258, 1959.

21) Laemmli, U.K.: Cleavage of structural protein during the assembly of the head of bacteriophage T4. Nature, 227, $680 \sim 685,1970$.

22) Lowry, O.H., Rosenbrough, N.J., Farr, L. and Randall, R. J. : Protein measurement with the Folin phenol reagent. J. Biol. Chem., 193, 265 275, 1951.

23) Vesterberg, O.: Isoelectric focusing of proteins. Methods Enzymol., 22, 389 412, 1971.

（受付：1986年12月24日） 